\title{
The impact of consumers' traveling and media activities on consumer behaviour towards purchasing global brands
}

\author{
Jovana Filipović ${ }^{1 *}$, Srđan Šapić ${ }^{1}$ \\ ${ }^{1}$ University of Kragujevac, Faculty of Economics, Kragujevac, Serbia
}

\begin{abstract}
The main objective of this research is an analys is of the impact that consumer travel and the presence of global brands in the media have on the attitudes and intentions which consumers have regarding the purchase of these brands. In order to analy se previously mentioned relationships between the variables, an empirical study was conducted as well as statisticalanalysis of the obtained data. Testing of hypotheses and relationships between variables was performed using structural equation modelling (SEM). The research results indicate that consumer travel and media activities of global companies have a positive and statis tically significant impact on attitudes which consumers have regarding the purchase of global brands, and that attitudes have a very strong and positive impact on consumers' intentions regarding future purchas es of global brands. In addition, it has been found that female consumers, younger and middle-aged consumers, as well as consumers with higher levels of education are more prone to form intentions regarding the purchase of global brands. The study contributes to the existing scientific literature in the field of international marketing and brand management, since there are a certain number of papers in the field of globalbranding in the foreign scientific literature, while in the domestic scientific literature the mentioned area is relatively unexplored.
\end{abstract}

Keywords: global brand, consumer travel, media activities, attitudes and behavioural intentions

JEL clas sification: M31

\section{Uticaj putovanja potrošača i medijskih aktivnosti kompanija na ponašanje potrošača prema kupovini globalnih brendova}

Sažetak: Predmet ovog radajeste analiza faktora koji ostvaruju uticaj na stavove i namere potrošača prema globalnimbrendovima. Shodno to me, osnovni cilj ovog istraživanja jeste analiza uticaja putovanja potrošača, kao i prisus tva brendova u medijs kim aktivnostima, na stavoveinamere potrošača u pogledu kupovine globalnih brendova. Radi analize prethodno spomenutih veza između posmatranih varijabli, sprovedeno je empirijsko is traživanje, kao i stat is tička obrada dobijenih podataka. Testiranje hipoteza iutvrđivanje veza između varijabli izvršeno je putemmodela strukturalnih jednačina (SEM). Rezultati is traživanja ukazuju da faktori putovanja potrošača i medijske aktivnosti globalnih kompanija imaju pozitivan i

\footnotetext{
* jovanagolo@kg.ac.rs

** The article was presented in the previous version at a scientific conference of the Serbian Marketing Association in the form of an oral announcement (under the same title).
} 
Filipović, J., Šapić, S. - The impact of consumers' traveling and media activities on consumer behaviour towards purchasing global brands - Hotel and Tourism Management, 2020, Vol. 8, No. 1:25-35.

statistički značajan uticaj na stavove koje potrošači imaju u pogledu kupovine globalnih brendova, kao i da stavovi imaju veoma jak i pozitivan uticaj na namere koje potrošači imaju u pogledu buduće kupovine globalnih brendova. Pored toga, utvrđeno je da su potrošači ženskog pola, potrošači mlađe i srednje starosne grupe, kao i potrošači sa višim nivoom obrazovanja skloniji formiranju namera u vezi sa kupovinom globalnih brendova. Is traživanje predstavlja doprinos pos tojećoj naučnoj literaturi iz oblasti marketinga i brend menadžmenta, s obzirom da u stranoj naučnoj literaturi postoji određeni broj radova iz oblastiglobalnog brendiranja, dok je u domaćojnaučnoj literaturinavedena oblast relativno neistražena.

Ključne reči:globalnibrend, putovanja potrošača, medijs ke aktivnosti kompanija, stavovi i namere potrošača

\section{JEL klasifikacija: M31}

\section{Introduction}

Globalization is result of factors including "worldwide investment, production and marketing, advances in telecommunication technologies and the internet, increases in world travel and the growth of global media" (Alden et al., 2006, p. 227; Holt et al., 2004). Some authors (e.g., Hannerz, 1990; Levitt, 1983) have claimed that "these trends cause the formation of a global consumer culture" (Alden et al., 1999, p. 76). This culture is described as "interest in global products and brands and by global consumer segments with similar interes ts in products and consumption activities that associate similar meanings with certain places, people, and things" (Nijss en \& Douglas, 2011, p. 114). In accordance with that, in the marketing literature since the 80 's onwards, there is an emphasized homogenization at the global level of consumers' needs, desires and tastes (Levitt, 1983). Consequently, multinational and global companies are increasingly offering standardized, global products and services (Keillor et al., 2001). Global companies develop global brands, which, "from supply side, can create economies of scale and scope in research and development, manufacturing, sourcing, and marketing for these companies, and from demand side, global brands, with their consistent positioning, may benefit from a unique perceived image worldwide" (Özs omer \& Altaras, 2008, p. 1).

Global brands can be defined as the "brands that consumers can find under the same name in multiple countries with generally standardized and centrally coordinated marketing strategies" (Özsomer, 2012, p. 72; Schuiling \& Kapferer, 2004; Steenkamp et al., 2003). Similarly, global brands are defined as "those that have widespread regional/global awareness, availability, acceptance, and demand and are often found under the same name with cons is tent positioning, personality, look, and feel in major markets enabled by centrally coordinated marketing strategies and programs" (Özsomer \& Altaras, 2008, p. 1). Also, global brands are defined as "brands that use the same marketing strategy and mix in all target markets" (Levitt, 1983; Schuiling \& Kapferer, 2004; Yip \& Hult, 2012). "While most researchers agree that wide availability and recognition are the key features of global brands, universal relevance, global image, standardization, esteem, high quality, and social responsibility are important as well" (Özsomer, 2012, p. 72).

Based on the relevant literature in the field of international marketing, we determined a research framework which includes the factors that influence consumers' attitudes and intentions towards purchasing global brands, and which are not frequently analysed. The purpose and aim of the conducted research is to analyse the impact that consumers' traveling and brand presence in media activities make on attitudes which consumers have regarding globalbrands, but also to analyse the impact that attitudes make on consumers' purchase 

purchasing global brands - Hotel and Tourism Management, 2020, Vol. 8, No. 1:25-35.

intentions. Having in mind the very pronounced influence and presence of multinational and globalcompanies in the modern business surroundings, it is very important to explore the reasons why consumers buy these companies' brands.

\section{The ore tical framework}

\subsection{Cons umers' traveling}

When people travel outside their home country and havecontact with foreign cultures, they gain knowledge of other cultures and their values. Such experiences influence people by reducing ignorance, misunderstanding and mistrust on a global level and foster social integration (Appadurai, 1990). From the marketing point of view, exposure to foreign cultures through migration and travel leads to greater openness and willingness of consumers to try new and foreign products, which they cannot find in their domestic market. Different types of travel and migration globally, influence the creation of positive attitudes and reactions which consumers have towards foreign products and services, when compared to domestic alternatives (Beckmann et al., 2001; Nijssen \& Douglas, 2011).

"Due to reducing barriers on a global level, the advancement of technology and easier access to fast and cheap means of transportation, mas s migration of people has become a hallmark of today's world, resulting in direct and indirect contacts between members of different cultures" (Cleveland \& Laroche, 2007, p. 252). This is happening not only because of businesstrips and tourism trips but also because of the increasing number of people who are moving abroad for their jobs, people visiting family members and friends in foreign countries and international movement of students (Wilk, 1998). Appadurai (1996) categorizes all "mass migrations into three types of cross-cultural interactions: 1) all types of traveling to foreign countries, 2) social contact with friends, family, and other people who have been abroad for some time, and 3) social contact with foreigners" (p. 147). He points out, in fact, that through all these types of migration, and most of all through travel, it is possible to spread the so-called global culture and to increase its distribution.

Numerous studies have shown that consumers who have more experience with foreign cultures, through various forms of international travel, also have a more positive attitude towards global alternatives reg arding products and services (Alden et al., 2006; Cleveland et al., 2011; Nijs sen \& Douglas, 2008; Nijs sen \& Douglas, 2011; Wilk, 1998). Implications of these findings can be of great importance from the pers pective of tourism sector, given the increasing migration, travel and the reduction of barriers between countries, on a globallevel (Pavlek, 2000). Thus, companies fromthe tourism sector, who invest in their brand and have a recognisable and widespread multinational and global presence and awareness, can have important benefits from the segment of consumers who travel frequently. Bearing in mind that frequent travellers are generally cosmopolitan-oriented and appreciate world-famous and omnipresent brands, it can be assumed that they will want to use the services of world renowned restaurants, hotels, transport companies, etc. (Šapić et al., 2019). These consumers often choose recognizable international and globalbrands (such as McDonald`s, Starbucks, or franchise hotels), due to their standardized service offerings and quality, wide spread presence in many countries and consumers' familiarity with them. Keeping in mind all given theoretical as sumptions, results of previous studies, and that attitudes refer to the "positive or negative feelings which a person has regarding object behaviour" (Fis hbein \& Ajzen, 1975, p. 216), but also an enduring, general as sessment of people, objects, advertis ements or social is sues (Baron \& Byrne, 1987), we defined the first general hypothesis: 
Filipović, J., Šapić, S. - The impact of consumers' traveling and media activities on consumer behaviour towards purchasing global brands - Hotel and Tourism Management, 2020, Vol. 8, No. 1:25-35.

H1: Consumers ' travels have a positive and statistically significant impact on consumers' attitudes towards purchasing global brands.

\subsection{Media activities of global companies}

"Exposure to the global mass media and marketing activities of multinational and global companies is one of the main factors which have a positive influence on consumers' attitudes towards the global consumer culture, whose main carriers are precisely global brands" (Cleveland et al., 2016, p. 1092). "Access to television and other forms of mass media around the world has helped to create a global culture of consumption. European, Asian, and especially American television shows and films are getting increasingly available worldwide" (Cleveland \& Laroche, 2007, p. 252). "If consumers largely choose the mass media (films, television and magazine content) from foreign countries, they are likely to be exposed to multicultural experiences and, with increasing knowledge, they should develop a more positive attitude towards consumption alternatives which are outside their home environment" (Alden et al., 2006, p. 231).

In addition to this, Walker(1996) "concluded that the accessto television worldwide has led to the creation of a global consumer culture, which he calls a global shopping mall" (p. 42). Similarly, Appadurai (1990) and Alden et al. (1999, p. 75) have argued "that mass media content, primarily of American descent, plays an important role in the creation, learning, and sharing of consumers' symbols (including, for example, product categories, brands, and consumers' activities)". For those living in a relatively homogeneous environment, the omnipresent global media provides an opportunity for imagining contact with outside cultural groups. The marketing and media activities which multinational and global companies implement collectively bear a great responsibility for spreading the global consumer culture (Peñaloza \& Gilly, 1999).

Given that many contemporary brands are more concerned with the trans fer of meaning and less with product features, media activities are of great importance for the international and global success of thesebrands, by influencing the attitudes and intentions of consumers. This is of particular importance to the services sector, such as the tourism sector, in which the intangible elements of the brand and service offering are emphasized (Anholt, 1999). Multinational and global companies in touris msector (such as hotel and restaurant chains) usually have brands that are well known in the international or global level, which consumers can find in many markets, as well as standardized marketing mix. Therefore, many hotels, restaurants and transport companies, es pecially international and global ones, use media campaigns as a means of influencing the attitudes and intentions of their consumers in different markets on a global level. Furthermore, in today's competitive environment, global companies in tourism sector use different media activities, such as social net works and online dis tribution channels to improve their business performance, through their influence on consumers`attitudes and intentions (Vrkljan \& Bognar, 2017). Based on the all previous statements and results of previous studies, hypothesis $\mathrm{H} 2$ can be defined:

H2: Brand presence in the media has a positive and statistically significant impact on consumers' attitudes towards purchasing global brands.

\subsection{Attitudes and intentions towards global brands}

Attitudes refer to the "positive or negative feelings (affective judgment) which a person has regarding object behaviour"'(Fis hbein \& Ajzen, 1975, p. 216). Therefore, the consumer will probably engage in some form of behaviour if he or she evaluates it positively. Attitudes are formed based on cognitive factors, such as needs, expectations and values. As a 

purchasing global brands - Hotel and Tourism Management, 2020, Vol. 8, No. 1:25-35.

consequence, attitudes influence the intensity of individuals' intentions (Atkins on, 1964). A similar opinion is shared by Ajzen and Fishbein (1980), who "argue that intentions are strongly influenced by the attitudes of individuals, with response and action as the ultimate results of this". Behavioural intentions are defined as "the strength of an individual's intention to commit a particular type of behaviour" (Fishbein \& Ajzen, 1975, p. 288). In addition, intentions influence actual behaviour of consumers, which ind icates that it's more probable that certain behaviour will be performed, if intentions regarding this behaviour are strong.

While designing the research and conceptual model, we incorporated certain elements of The Theory of Reasoned Action - TRA (Ajzen \& Fishbein, 1980) and the Theory of Planned Behaviour - TPB (Ajzen, 1991), which imply that "consumers' attitudes and assessments determine their behavioural intentions, and those intentions determine actual consumer behaviour". A similar approach has been used in numerous earlier studies (Zeugner-Roth et al., 2015). In line with the theoretical claims stated above, the third hypothesis of this research can be defined.

H3: Consumers ' attitudes have a positive and statis tically significant impact on consumers' intentions towards purchasing global brands.

\section{Research methodology}

Empirical survey was conducted with the purpose of testing previously established hypotheses. In the survey, the total number of 185 ques tionnaires was collected. The sample structure is such that the biggest percentage of respondents are women (52\%), and members of the younger and middle generations, with high-school education (62.8\%). The survey was conducted during May and June 2019 on the territory of the city of Kragujevac. The data were obtained by dis tributing the questionnaire personally, whereby the statements in the questionnaire were rated on a seven-point Likert scale (where 1 means - strongly dis agree, 7strongly agree) by the respondents.

The variables used were measured through statements that were taken from relevant scientific studies and adapted for the purposes of this res earch. The statements regarding the travelvariable were taken from a study conducted by Cleveland and Laroche (2007). The statements regarding the variable brand presence in media activities were also taken from a study by Cleveland and Laroche (2007). Statements related to the variable of consumers' attitudes towards global brands have been taken and adapted from the studies by Sharma (2011), followed by Yoo and Donthu (2005), as well as Nijssen and Douglas (2004). The statements regarding the variable related to consumers' intentions were taken from the studies conducted by Sharma (2011) and Yoo and Donthu (2005).

Statistical processing and analysis of data were performed by using SPSS software package (21.0) and AMOS software (23.0). The confirmatory factor analysis was used for the measurement of the model validity, with adequate indexes. After this, the analys is of the impact of variables from the model on consumers' attitudes, and also the influence of attitudes on consumers' intentions concerning the purchase of global brands, was performed using the structural equation modelling (SEM). In this way, we performed the testing of the hypothesis. At the end of the analysis, the influence of control variables on the dependent variables in the research model was examined. 


\section{Results and discussion}

The validity indicators for the research model are shown in Table 1. Having in mind that the value of the indicator $\chi 2 /$ df should be less than 3 (Bagozzi \& Yi, 1988), it can be observed that this condition is met. The IFI, CFI and TLI index values should be above 0.9 (Byrne, 1998), so it can be concluded that the modelmeets these validity conditions as well. In the end, the recommended value of the RMSEA indicator is lower than 0.08 (Hair et al., 2006), which is also a condition met in the model.

Table 1: The validity indicators for the research model

\begin{tabular}{|c|c|}
\hline Indicators & Research model \\
\hline$\chi 2 / \mathrm{df}$ & 1.625 \\
\hline IFI & 0.946 \\
\hline TLI & 0.933 \\
\hline CFI & 0.945 \\
\hline RMSEA & 0.072 \\
\hline
\end{tabular}

Source: Author's research

Conducted confirmatory factor analysis, which is presented in Table 2, indicates that the values of the average variance extracted (AVE) for all analys ed variables are ab ove the 0.50 , which is the recommended value in the literature (Fornell \& Larcker, 1981). Therefore, the model meets the requirements for convergent validity. Furthermore, all variables in the research model have a higher value than the recommended level of 0.7 with regards to composite reliability (CR) values (Fornell \& Larcker, 1981).

Apart from that, the analysis of the Cronbach's alpha coefficient revealed that variables in the model had adequate values, which are higher than the recommended value of 0.7 (Nunnally, 1978). In addition to the above-given results, it should be noted that the largest number of findings has very high values of fact or loading (higher than 0.7 ), while for one statement, the value of factor loading exceeds 0.5 , which is considered acceptable (Hair et al., 2006). Based on the values of the calculated squared correlations between the observed variables, and also on the values of the AVE for each variable, it is determined that the model meets the requirements for discriminant validity. More specifically, AVE value for every variable is higher than the squared values of the correlations between the given variable and other analysed variables in the model.

Table 2: The results of confirmatory factor analys is

\begin{tabular}{|l|c|c|c|c|}
\hline Statements & $\begin{array}{c}\text { Factor } \\
\text { loading }\end{array}$ & $\begin{array}{c}\text { Cronbach's } \\
\boldsymbol{\alpha}\end{array}$ & AVE & CR \\
\hline Consumers' traveling & & $\mathbf{0 . 7 3 7}$ & $\mathbf{0 . 5 2 7}$ & $\mathbf{0 . 8 1 3}$ \\
\hline $\begin{array}{l}\text { I prefer spending my vacation in a foreign } \\
\text { country to spending it in my country. }\end{array}$ & 0.625 & & & \\
\hline I have travelled a lot outside my country. & 0.677 & & & \\
\hline $\begin{array}{l}\text { Traveling and visiting foreign countries are } \\
\text { some of my favourite activities. }\end{array}$ & 0.913 & & & \\
\hline $\begin{array}{l}\text { I often think about visiting foreign } \\
\text { countries and about traveling in general. }\end{array}$ & 0.651 & & & \\
\hline Media activities of global companies & & $\mathbf{0 . 7 7 9}$ & $\mathbf{0 . 5 3 1}$ & $\mathbf{0 . 8 1 5}$ \\
\hline $\begin{array}{l}\text { Global brand ads are everywhere and they } \\
\text { are very common. }\end{array}$ & 0.698 & & & \\
\hline
\end{tabular}




\begin{tabular}{|l|l|l|l|l|}
\hline $\begin{array}{l}\text { It is very common to see commercials for } \\
\text { global brands in domestic media. }\end{array}$ & 0.895 & & & \\
\hline $\begin{array}{l}\text { There are a lot of ads for global brands in } \\
\text { the newspapers and magazines I read. }\end{array}$ & 0.723 & & & \\
\hline $\begin{array}{l}\text { When I watch TV, it seems like there are } \\
\text { many more commercials for global brands } \\
\text { than for domestic ones. }\end{array}$ & 0.561 & & & \\
\hline $\begin{array}{l}\text { Attitudes towards purchasing global } \\
\text { brands }\end{array}$ & & $\mathbf{0 . 9 1 1}$ & $\mathbf{0 . 7 0 1}$ & $\mathbf{0 . 9 0 3}$ \\
\hline Purchasing global brands is a good idea. & 0.835 & & & \\
\hline $\begin{array}{l}\text { Purchasing global brands is an attractive } \\
\text { idea. }\end{array}$ & 0.752 & & & \\
\hline Purchasing global brands is a wise idea. & 0.904 & & & \\
\hline $\begin{array}{l}\text { In my opinion, it is preferable to purchase } \\
\text { global brands. }\end{array}$ & 0.851 & & $\mathbf{0 . 7 9 5}$ & $\mathbf{0 . 9 5 1}$ \\
\hline $\begin{array}{l}\text { Intentions regarding the purchase of } \\
\text { global brands }\end{array}$ & & & & \\
\hline $\begin{array}{l}\text { I intend to purchase global brands in the } \\
\text { near future. }\end{array}$ & 0.912 & & & \\
\hline $\begin{array}{l}\text { I am going to purchase global brands in the } \\
\text { future. }\end{array}$ & 0.927 & & & \\
\hline $\begin{array}{l}\text { In the future, I intend to purchase global } \\
\text { brands for most of my needs. }\end{array}$ & 0.913 & & & \\
\hline $\begin{array}{l}\text { I believe that my interest in purchasing } \\
\text { global brands will increase in the future. }\end{array}$ & 0.851 & & & \\
\hline $\begin{array}{l}\text { I will strongly recommend purchasing } \\
\text { global brands to other people. }\end{array}$ & 0.851 & & & \\
\hline Soure: Authrs rearch & & & \\
\hline
\end{tabular}

Source: Author's research

The SEM was applied to analy se the relationships in the established model. Based on the results presented in Table 3, it can be observed that all three hypotheses were accepted. Consumers' traveling has a statistically significant and positive impact on attitudes which consumers have towards purchasing global brands $(\beta=0.421, \mathrm{p}<0.001)$, thus confirming hypothesis H1. Also, the presence of brands in the media activities of companies $(\beta=0.202$, $\mathrm{p}<0.05)$ has a statis tically significant and positive impact on attitudes which consumers have towards purchasing global brands, based on which the hypothes is $\mathrm{H} 2$ can be confirmed. It should be noted that consumers ' travels have a much stronger impact on consumers' attitudes than the presence of brands in the media activities of global companies. Finally, consumers' attitudes have a very strong and positive influence on their intentions regarding the future purchase of global brands $(\beta=0.801, \mathrm{p}<0.001)$, thus confirming hypothes is $\mathrm{H} 3$.

Table 3: Testing the relationships between variables (SEM)

\begin{tabular}{|l|c|c|}
\hline Hypothesis & Assessment & Conclusion \\
\hline $\begin{array}{l}\text { H1: Consumers' Traveling } \rightarrow \text { Consumers' Attitudes } \\
\text { towards buying Global Brands }\end{array}$ & $0.421^{* * *}$ & Accepted \\
\hline $\begin{array}{l}\text { H2: Brand Pres ence in Media Activities } \rightarrow \text { Consumers' } \\
\text { Attitudes towards Buying Global Brands }\end{array}$ & $0.202^{* *}$ & Accepted \\
\hline $\begin{array}{l}\text { H3: Consumers' Attitudes towards Buying GlobalBrands } \\
\rightarrow \text { Intentions towards Buying Global Brands }\end{array}$ & $0.801^{* * *}$ & Accepted \\
\hline
\end{tabular}


Filipović, J., Šapić, S. - The impact of consumers' traveling and media activities on consumer behaviour towards purchasing global brands - Hotel and Tourism Management, 2020, Vol. 8, No. 1:25-35.

\begin{tabular}{|l|c|l|c|}
\hline \multicolumn{4}{|l|}{ Control variables } \\
\hline $\begin{array}{l}\text { Gender } \rightarrow \text { Consumers' } \\
\text { attitudes }\end{array}$ & $0.106^{\mathrm{ns}}$ & $\begin{array}{l}\text { Gender } \rightarrow \text { Consumers' } \\
\text { intentions }\end{array}$ & $0.109^{* *}$ \\
\hline $\begin{array}{l}\text { Age } \rightarrow \\
\text { attitudes }\end{array}$ & $0.024^{\mathrm{ns}}$ & $\begin{array}{l}\text { Age } \rightarrow \\
\text { intentions }\end{array}$ & $0.124^{* * *}$ \\
\hline $\begin{array}{l}\text { Education } \rightarrow \text { Consumers' } \\
\text { attitudes }\end{array}$ & $-0.031^{\mathrm{ns}}$ & $\begin{array}{l}\text { Education } \rightarrow \text { Consumers' } \\
\text { intentions }\end{array}$ & $0.135^{* * *}$ \\
\hline $\begin{array}{l}\text { Employment status } \rightarrow \\
\text { Consumers' attitudes }\end{array}$ & $0.052^{\mathrm{ns}}$ & $\begin{array}{l}\text { Employment status } \\
\text { Consumers'intentions }\end{array}$ & $0.081^{\mathrm{ns}}$ \\
\hline
\end{tabular}

Note: $* * *$ - significant for $\mathrm{p}<0.001 ; * *$ - significant for $\mathrm{p}<0.05$; ns - not significant Source: Author's research

The obtained results indicate that gender, age and education, as control variables, have a positive influence on intentions which consumers have towards the purchase of global brands. Specifically, it has been found that female members, younger and middle-aged consumers, as well as consumers with higher levels of education (college education) have higher tendency to form intentions regarding the purchase of global brands. The control variables mentioned above do not have a statistically significant influence on attitudes which consumers have towards purchasing global brands.

\section{Conclusion}

The purpose of conducted empirical study was the analys is of the variables which have an impact on the attitudes and intentions of consumers towards global brands. More specifically, factors which are analysed in this study are consumers` traveling and media activities of global companies. Empirical res earch has shown that consumers' traveling and media activities of global companies have a statis tically significant and positive impact on attitudes which consumers have towards purchasing global brands. Similar results have been obtained in previous studies (Alden et al., 2006; Cleveland \& Laroche, 2007; Cleveland et al., 2016; Nijssen \& Douglas, 2008; Nijssen \& Douglas, 2011). In addition to that, consumers' attitudes have a very strong impact on their intentions for the future purchase of globalbrands, which justifies the use of the Theory of planned behaviour and the Theory of reas oned action as the theoretical bas is for the res earch model. These results indicate that all three res earch hypotheses are confirmed. In addition to the previously mentioned results, the research concerning the influence of control variables revealed that female members, consumers of the younger and middle-aged groups, as well as consumers with higher levels of education have a higher tendency of forming intentions regarding the purchase of global brands.

The conducted res earch contributes to the scientific literature in the field of marketing and internationalbrand management. Even though there are some papers in the field of global branding in the foreign scientific literature, in the domestic scientific literature the aforementioned area is relatively unexplored. Additionally, the results that we obtained can be very important for the management of marketing activities of domestic and international companies, es pecially when it comes to understanding the importance of the analy sed factors for consumers' decision making regarding the purchase of global brands.

Such knowledge can be of particular importance to the touris $m$ sector, because factors like media activities encourage the use of well-known and established hotels and restaurants brands, which are usually owned by global companies and operate on foreign markets through franchises (such as Hilton, Radiss on, Starbucks, McDonald's, etc.). In fact, many hotels, restaurants and transport companies, especially international and global ones, use 

purchasing global brands - Hotel and Tourism Management, 2020, Vol. 8, No. 1:25-35.

media campaigns as a means of influencing the attitudes and intentions of their consumers in different markets globally. Furthermore, consumers who enjoy traveling tend to be more familiar with such global, ubiquitous hotel and restaurantbrands, which can lead to their use of the services of these brands. These consumers often choose recognizable international and globalbrands (such as McDonald`s, etc), due to their standardized service offerings and quality, wides pread presence in many countries and consumers' familiarity with them. This implies that this segment of consumers is es pecially important for these types of companies and brands. Therefore, insights from this research can contribute to the creation of communication and customer relationship management strategies, as well as the market segmentation of companies.

Apart from this, the conducted research has some limitations. The basic limitation of the study is that other variables which may influence consumers' attitudes towards global brands, such as brand prestige, materialism, consumers' animosity, are not included in the research model. Future res earch may include analysing the influence of additional variables, such as brand prestige, quality, animosity, ethnocentrism, and other variables on consumers' attitudes and intentions regarding the purchase of global brands.

\section{References}

1. Ajzen, I. (1991). The theory of planned behavior. Organizational Behavior and Human Decision Processes, 50(2), 179-211. https://doi.org/10.1016/0749-5978(91)90020-t

2. Ajzen, I., \& Fishbein, M. (1980). Understanding attitudes and predicting social behavior. Englewood Cliffs, NJ: Prentice-Hall.

3. Alden, D. L., Steenkamp, J-B. E. M., \& Batra, R. (1999). Brand positioning through advertising in Asia, North America, and Europe: The role of global consumer culture. Journal of Marketing, 63(1), 75-87. https://doi.org/10.2307/1252002

4. Alden, L. D., Steenkamp, J-B. E. M., \& Batra, R. (2006). Consumer attitudes toward marketplace globalization: structure, antecedents and consequences. International Journal of Research in Marketing, 23(2), 227-239. https://doi.org/10.1016/j.jires mar.2006.01.010

5. Anholt, S. (1999). Travel and touris m companies: Global brands. Journal of Vacation Marketing, 5(3), 290-295. https://doi.org/10.1177/135676679900500308

6. Appadurai, A. (1990). Disjuncture and differencein the global cultural economy. Theory, Culture \& Society, 7(2), 295-310. https://doi.org/10.1177/026327690007002017

7. Appadurai, A. (1996). Modernity at large: cultural dimensions of globalization. Minneapolis, MI: University of Minnesota Press.

8. Atkins on, J. W. (1964). An Introduction to Motivation. Princeton, NJ: Van Nostrand.

9. Bagozzi, R. P., \& Yi, Y. (1988). On the evaluation of structural equation model. Journal of the Academy of Marketing Science, 16(1), 74-94. https://doi.org/10.1007/bf027

10. Baron, R. A. \& Byrne, D. (1987). Social psychology: Understanding human interaction (5th ed.). Boston: Allyn \& Bacon.

11. Beckmann, S., Botschen, G., Botschen, M., Douglas, S. P., Friese, S., \& Nijssen, E. J. (2001). The worldminded consumer: An emic exploration. Advances in Consumer Research, 28, 138.

12. Byrne, B. M. (1998). Structuralequation modeling with LISREL, PRELIS, and SIMPLIS: Basic concepts, applications, and programming. Hills dale, NJ: Lawrence Erlbaum.

13. Cleveland, M., \& Laroche, M. (2007). Acculturaton to the global consumer culture: Scale development and research paradigm. Journal of Business Research, 60(3), 249-259. https://doi.org/10.1016/j.jbusres .2006.11.006 
Filipović, J., Šapić, S. - The impact of consumers' traveling and media activities on consumer behaviour towards purchasing global brands - Hotel and Tourism Management, 2020, Vol. 8, No. 1:25-35.

14. Cleveland, M., Erdoğan, S., Arikan, G., \& Poyraz, T. (2011). Cosmopolitanism, individual-level values and cultural-level values: A cross-cultural study. Journal of Business Research, 64, 934-943. https://doi.org/10.1016/j.jbusres.2010.11.015

15. Cleveland, M., Rojas-Mendez, J. I., Laroche, M., \& Papadopoulos, N. (2016). Identity, culture, dispositions and behavior: A cross -national examination of globalization and culture change. Journal of Business Research, 69(3), 1090-1102. https://doi.org/10.1016/j.jbusres.2015.08.025

16. Fishbein, M., \& Ajzen, I. (1975). Belief, attitude, intention and behavior: An introduction to theory and research. Reading, Boston: Addison-Wesley.

17. Fornell, C., \& Larcker, D. F. (1981). Evaluating structural equation models with unobservable variables and measurement error. Journal of Marketing Research, 18(1), 39 50. https://doi.org/10.1177/002224378101800104

18. Hair, J. F., Black, W. C., Babin, B., Anders on, R., \& Tatham, R. (2006). Multivariate Data Analysis (6th ed.). Upper Saddle River, NJ: Prentice Hall.

19. Hannerz, U. (1990). Cosmopolitans and Locals in World Culture. Theory, Culture \& Society, 7(2-3), 237-251. https ://doi.org/10.1177/026327690007002014

20. Holt, D. B., Quelch, J. A., \& Taylor, E. L. (2004). How globalbrands compete. Harvard Business Review, 82(9), 68-75.

21. Keillor, B. D., D'Amico, M., \& Horton, V. (2001). Global consumer tendencies. Psychology and Marketing, 18(1), 1-19. https://doi.org/10.1002/15206793(200101)18:1<1::aid-mar1>3.0.co;2-u

22. Levitt, T. (1983). The globalization of markets. Harvard Business Review, 61(3), 39-49.

23. Nijssen, E. J., \& Douglas, S. P. (2004). Examining the animosity model in a country with a high level of foreign trade. International Joumal of Research in Marketing , 21(1), 2338. http://doi.org/bt6rz3

24. Nijssen, E. J., \& Douglas, S. P. (2008). Consumer world-mindedness, social-mindedness, and store image. Journal of International Marketing, 16(3), 84-107. https://doi.org/10.1509/jimk.16.3.84

25. Nijssen, E. J., \& Douglas, S. P. (2011). Consumer world-mindedness and attitudes toward product positioning in advertising: An examination of global versus foreign versus local positioning. Journal of International Marketing, 19(3), 113-133. https ://doi.org/10.1509/jimk.19.3.113

26. Nunnally, J. C. (1978). Introduction to psychological measurement, New York, NY: McGraw-Hill.

27. Özsomer, A. (2012). The interplay between global and local brands: A closer look at perceived brand globalness and local iconness. Journal of International Marketing, 20(1), 72-95. https://doi.org/10.1509/jim.11.0105

28. Özs omer, A., \& Altaras, S. (2008). Global brand purchase likelihood: A critical synthesis and an integrated conceptual framework. Journal of International Marketing, 16(4), 128. https ://doi.org/10.1509/jimk.16.4.1

29. Pavlek, Z. (2000). Globalne marke u turizmu i prehrambenoj industriji [Global brands in cases from tourism and food industry]. Acta Turistica, 12(2), 173-197.

30. Peñaloza, L., \& Gilly, M. C. (1999). Marketer acculturation: The changer and the changed. Journal of Marketing, 63(3), 84-104. https://doi.org/10.1177/002224299906300306

31. Šapić, S., Filipović, J., \& Dlačić, J. (2019). Consumption in fast-food restaurants in Croatia and Serbia. British Food Journal, 121(8), 1715-1729. https://doi.org/10.1108/BFJ-04-2018-0264

32. Schuiling, I., \& Kapferer, J-N. (2004). Executive insights: Real differences between local and internationalbrands: Strategic implications for international marketers. Journal of International Marketing, 12(4), 97-112. https://doi.org/10.1509/jimk.12.4.97.53217 

purchasing global brands - Hotel and Tourism Management, 2020, Vol. 8, No. 1:25-35.

33. Sharma, P. (2011). Country of origin effects in developed and emerging markets: Exploring the contrasting roles of materialism and value consciousness. Journal of International Business Studies, 42(2), 285-306. https://doi.org/10.1057/jibs.2010.16

34. Steenkamp, J-B. E. M., Batra, R., \& Alden, D. L. (2003). How perceived brand globalness creates brand value. Journal of International Business Studies, 34(1), 53-65. https://doi.org/10.1057/palgrave.jibs.8400002

35. Vrkljan, S., \& Bognar, Z. B. (2017). The model of key competitive factors of global chain hotels. 4th International Scientific Conference ToSEE - Tourism in Southern and Eastern Europe 2017 "Tourism and Creative Industries: Trends and Challenges" Opatija, Croatia, 4 - 6 May 2017, 631-644.

36. Walker, C. (1996). Can TV save the planet?. American Demographics, (May 18), 42-49.

37. Wilk, R. (1998). Emulation, imitation, and global consumerism. Organization and Environment, 11(3), 314-333. https://doi.org/10.1177/0921810698113003

38. Yip, G., \& Hult, G. T. M. (2012). Total global strategy (3rd ed.). Boston, MA: Pearson.

39. Yoo, B., \& Donthu, N. (2005). The effect of personal cultural orientation on consumer ethnocentrism. Journal of International Consumer Marketing, 18(1-2), 7-44. https://doi.org/10.1300/j046v18n01_02

40. Zeugner-Roth, K. P., Žabkar, V., \& Diamantopoulos, A. (2015). Consumer ethnocentrism, national identity, and consumer cosmopolitanis m as drivers of consumer behavior: A social identity theory perspective. Journal of International Marketing, 23(2), 25-54. https://doi.org/10.1509/jim.14.0038 